\title{
Studying the Synergistic Effect of both Propolis Extract and Green Apple Peel Extract with Fluconazole against Candida albicans
}

\author{
Mohammed Y. Allawi \\ Department of Environmental Science / College of Environmental Sciences and Technology/ \\ University of Mosul \\ E-mail: mohammedallawy@gmail.com
}

(Received 14 / 5/ 2018 ; Accepted 10 / 10 / 2018)

\begin{abstract}
Candida albicans were isolated from 36 isolates of the mouth people aged (2.5 - 63) years. A crude sample of bees propolis was collected from several apiaries in Mosul city and green apples were collected from the markets, evaluating antifungal of fluconazole, methanol extract of propolis (MPE) and methanol extract of green apples peels (MEGAP) were different concentration $(125,250,375,500,750,1000,1500) \mathrm{ug} / \mathrm{ml}$, each one alone and as combination of (fluconazole $50 \%{ }^{+}$ MPE 50\%) and of (fluconazole 50\%+ MEGAP50\%). Each one alone, the fluconazole only had inhibitory effect against C.albicans. As combination, the synergistic effect was observed of both combination (fluconazole 50\% + EMP 50\%) and (fluconazole 50\%+MEGAP 50\%) against C.albicans. In comparing between two combination observed that it was outdoing in a synergistic effect of (EMP) compared with (EMGAP) specially at concentrations $(750,1000,1500) \mathrm{ug} / \mathrm{ml}$.
\end{abstract}

Keyword: Candida albicans, propolis, green apple peel, synergistic.

\section{درلسة التأثير التأزري لكلامنطسخاص المكبر ومستخاصقشور الفاح الأخضرمعمركب الفلوكونازط Candida albicans}

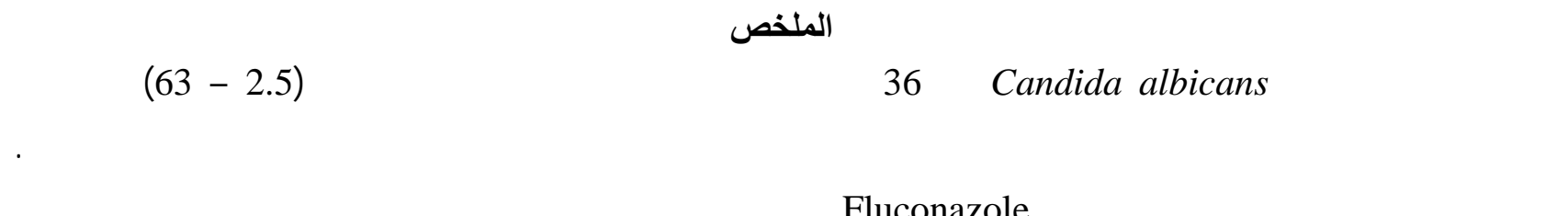
لختبرت فعالية كل من المركب الدوائي Fluconazole، ومستخلص العكبر الميثانولي ومستخلص قثدور الفاح الأخضر

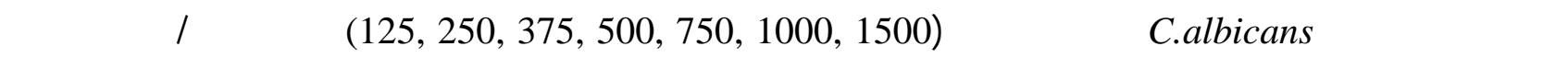
حله، وكلن لمركب Fluconazole فعالية تشبطية مضادة الفطر دون المستخلصن الأخيرين. وعند درلسة التأثير التعاوني

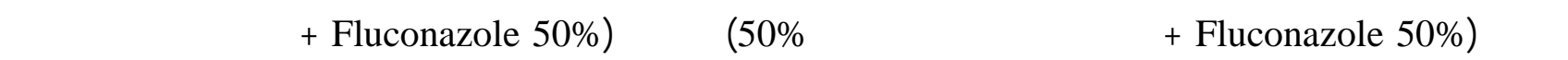

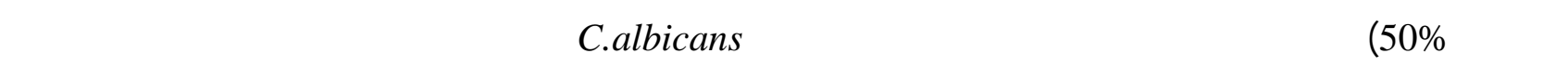
لمستخلص العكبر مع مركب Fuconazole مقارنة مع التأثير التعاوفي لمستخلص قثور الفاح الأخضر ولإسيما عند التركيز (750, 1000, 1500)

الهاملت الدالة: Candida albicans، العكبر، قشور القاح الأخضر، التآزر. 


\section{INTRODUCTION}

In recent times, there has been a rapid increase in fungal infections globally and this could be attributed mainly to increased susceptibility of individuals to infection due to immunosuppression and invasive drug therapy (Schmidt-Westhausen et al., 2004; Sims et al., 2005; Schwab et al.,1997) reported the increased adherence of Candida albicans to buccal epithelial cells obtained from AIDS patients compared to non-sufferers. Multiple resistant phenotypes of C.albicans have been found to coexist during episodes of oropharyngeal candidiasis in AIDS patients (Lopez- Ribot et al., 1999).C. albicans cells are protected by cell walls which mediate interaction with the host for adhesion and modulation of antifungal immune response in their host (Poulain and Jouault, 2004). Hence, the cell membrane may serve as a potential target for antifungal drugs. The mechanism of action of some anti-fungal drugs is by binding to the cell membrane of pathogenic fungi in the presence of certain sterols, which subsequently disturb permeability and transport characteristics of the membrane, resulting in loss of intracellular cations (Katzung, 1984). Apple tree belong to the family Rosaceae, subfamily Maloidea and genus Malus, being a fruit tree with highest importance worldwide, considered one of the main agricultural products (Victoretal, 2015). All sorts of apples have health benefits, but the thing that makes green apples special is that they have a high nutritional density packed with minerals, vitamins, protein and fiber (Barn-don, 2018).

Apple pulp contains catechin, procyanidin, caffeic acid and chlorogenic acid among other components. The skin contains all the afore mentioned substances as well as flavonoids, not present in pulp, such as quercetin glycosides and cyanidin glycosides (Escarpa and Gonzalez, 1998; Van der Sluis et al., 2001). Epidemiological studies associate phenolic consumption with lower mortality, especially caused by coronary diseases. They present multiple biological properties, which are of growing interest for consumers due to the high antioxidant, anti-inflammatory, anti allergic, anti thrombosis and antimicrobial activities (Kanner et al., 1994; Frankel et al., 1995; Koga et al., 1999; Eberhardt et al., 2000; Jayaprakasha et al., 2003; Baydar et al., 2004; Shoji et al., 2004).

The word propolis originates from Greek: «pro» = in front, "polis» = city. The meaning in front of the city, suits well the protecting role of propolis for the bee colony. The Greek word propolis means also to glue and describes also the role of propolis to cement openings of the bee hive. Another name of propolis is bee glue. Propolis was already known in ancient Egypt, where it was probably used as an adhesive. Propolis was mentioned by the Greek philosopher Aristoteles. In his Historiaanimalium it was referred to a substance which the bees smeared at the hive entrance and used as cure for bruises and sores (Crane, 1999). As the major constituents of propolis, flavonoids contribute greatly to the pharmacological activities of propolis. The quantity of flavonoids is used as a criterion to evaluate the quality of temperate propolis (Zhang et al., 2014) Flavonoids have a broad spectrum of biological properties, such as antibacterial, antiviral and antiinflammatory effects (Bueno-Silva et al., 2013; Nijveldt et al., 2001). According to the chemical structure, flavonoids in propolis are classified into flavones, flavonols, flavanones, flavanonols, chalcones, dihydrochalcones, isoflavones, isodihydroflavones, flavans, isoflavans and neoflavonoids. From 2000 to 2012, 112 flavonoids were identified in different type of propolis (Righi et al., 2011).

\section{Strains}

\section{MATERIALS AND METHODS}

Candida albicans was isolated from 36 isolates from the mouth of people aged $(2.5-63)$ years, using sabroud dextrose agar (SDA), and tryptone soya agar (TSA) as growth media, and using serum blood (SB) as diagnostic media, incubate in $37 \mathrm{C}^{\circ}$ for 24 day (Sagar, 2016; Bougnoux et al.,1999).

\section{Disc Diffusion Test}

Disc diffusion test was used as an alternative measure of susceptibility and a counterpart method of minimum inhibitory concentration (MIC) and maximum inhibitory concentration 
(MXIC), (NCCLS, 1996). Aseptically TSA plates were swabbed by C.albicans. Sterile paper discs $(6 \mathrm{~mm})$ were dipped in different dilution of (flucoconazole, green apple peels and propolis) each one alone and prepared combination of (fluconazole 50\%+propolis 50\%) and (fluconazole 50\% + green apple peels 50\%) in different dilution and placed on swab plates for C.albicans in specific dilutions and placed in media plate. In each dilution of each one was replicated thrice under factorial completely randomized design. Observed media plates and measured inhibition's zone from each paper disc in mm. If the test organism grows on the disc it may safely be assumed that the test organism is resistant $(\mathrm{R})$.

\section{The Extraction}

A crude sample of bees propolis was collected from several apiaries in Mosul city and green apples were isolated from market. Methanol of propolis extract (MPE) and methanol of green apple peels extract (MGAPE) were performed according to the method described by Ran et al.,with minor modification (Junjian et al., 2013). (MPE) and (MGAPE) were extracted $125 \mathrm{gm}$ with $500 \mathrm{ml}$ of methanol that mean $(1: 4)$, in an ultrasonic bath at $37 c^{\circ}$ for $40 \mathrm{~min}$. Two produced extracts were dried under negative pressure in rotary evaporation at $40 \mathrm{c}^{\circ}$ and then re-dissolved $4 \mathrm{~g}$ in $40 \mathrm{ml}$ of edible alcohol.

The extracts was filtered through a 0.45-um membrane (Millipore) and stored in refrigerator at $4 c^{\circ}$ until analysis. The evaluating anti fungal effects were different concentrations $(50,125,250$, $375,500,750,1000,1500)$ ug $-\mathrm{ml}$.

\section{RESULT AND DISCCUSION}

After evaluating different concentrations of disc dilution of (fluconazole, green apples peels and propolis) each one alone, It was observed that the fluconazole only had inhibitory effect against C.albicans (Table 1). The (MIC) of fluconazole drug was $2 \mathrm{~mm}$ at concentration (125) $\mathrm{ug} / \mathrm{ml}$, and (MXIC) was $3.6 \mathrm{~mm}$ at concentration (1500) ug/ml. While, the synergistic effect was observed of combination (fluconazole 50\% + MPE 50\% ) against C.albicans, the highest synergistic effect was $19.8 \%$ at concentration (1500)ug/ml , (Table 2).

Also there was a synergistic effect of combination (fluconazole 50\% + MGAPE 50\%), the highest synergistic effect was $12.9 \%$ at concentration (1500)ug/ml, (Table 3).

At comparing between (Table 2) and (Table 3) observed that it was outdoing in a synergistic effect of (MPE) on (MGAPE) specially at the last three concentration $(750,1000,1500) \mathrm{ug} / \mathrm{ml}$.

\section{Table 1: The inhibitory effect of fluconazole, (MPE) and (MGAPE) each one alone against C.albicans.}

\begin{tabular}{|c|c|c|c|c|c|}
\hline $\begin{array}{c}\text { Fluconazole } \\
\text { Concentration } \\
\mathbf{u g} / \mathbf{m l}\end{array}$ & $\begin{array}{c}\text { Average diameter } \\
\text { of inhibition } \\
\mathbf{( m m})\end{array}$ & $\begin{array}{c}\text { (MPE) } \\
\text { Concetration } \\
\mathbf{u g} / \mathbf{m l}\end{array}$ & $\begin{array}{c}\text { Average diameter } \\
\text { of inhibition } \\
\mathbf{( m m}\end{array}$ & $\begin{array}{c}\text { (MGAPE) } \\
\text { Concentration } \\
\mathbf{u g} / \mathbf{m l}\end{array}$ & $\begin{array}{c}\text { The } \\
\text { inhibitory } \\
\mathbf{M m}\end{array}$ \\
\hline 50 & $\mathrm{R}$ & 50 & $\mathrm{R}$ & $\mathrm{R}$ & $\mathrm{R}$ \\
\hline 125 & 2.0 & 125 & $\mathrm{R}$ & 250 & $\mathrm{R}$ \\
\hline 250 & 2.26 & 250 & $\mathrm{R}$ & 375 & $\mathrm{R}$ \\
\hline 375 & 2.3 & 375 & $\mathrm{R}$ & 500 & $\mathrm{R}$ \\
\hline 500 & 2.55 & 500 & $\mathrm{R}$ & 750 & $\mathrm{R}$ \\
\hline 750 & 3.05 & 750 & $\mathrm{R}$ & 1000 & $\mathrm{R}$ \\
\hline 1000 & 3.4 & 1000 & $\mathrm{R}$ & 1500 & $\mathrm{R}$ \\
\hline 1500 & 3.6 & 1500 & & & $\mathrm{R}$ \\
\hline
\end{tabular}


Table 2: The synergistic effect of combination (fluconazole $50 \%+$ MPE $50 \%$ ) against C.albicans.

\begin{tabular}{|c|c|c|c|c|c|c|}
\hline $\begin{array}{c}\text { Concentration } \\
\mathrm{ug} / \mathrm{ml}\end{array}$ & $\begin{array}{c}\text { Average } \\
\text { diameter } \\
\text { of inhibition } \\
(\mathrm{mm})\end{array}$ & $\begin{array}{c}\text { (MPE) } \\
\text { Concentrationug } \\
/ \mathrm{ml}\end{array}$ & $\begin{array}{c}\begin{array}{c}\text { Average } \\
\text { diameter } \\
\text { of } \\
\text { inhibition } \\
(\mathrm{mm})\end{array} \\
\end{array}$ & $\begin{array}{c}\text { Combination( } \\
\text { fluconazole } \\
+ \text { MPE) } \\
(\mathbf{5 0 \%}+\mathbf{5 0} \%) \\
\mathbf{u g} / \mathbf{m l}\end{array}$ & $\begin{array}{c}\begin{array}{c}\text { Average } \\
\text { diameter } \\
\text { of }\end{array} \\
\text { inhibition } \\
\text { (mm) }\end{array}$ & $\begin{array}{c}\text { A Synergistic } \\
\text { Percent of } \\
\text { combination } \\
\%\end{array}$ \\
\hline 125 & 1.8 & 125 & $\mathrm{R}$ & 250 & 1.85 & 2.7 \\
\hline 250 & 2.26 & 250 & $\mathrm{R}$ & 500 & 2.3 & 1.8 \\
\hline 375 & 2.3 & 375 & $\mathrm{R}$ & 750 & 2.76 & 16.7 \\
\hline 500 & 2.55 & 500 & $\mathrm{R}$ & 1000 & 3.0 & 15 \\
\hline 750 & 3.05 & 750 & $\mathrm{R}$ & 1500 & 3.8 & 19.8 \\
\hline
\end{tabular}

Table 3: The synergistic effect of combination (fluconazole $50 \%+$ MGAPE $50 \%$ ) against $C$. albicans.

\begin{tabular}{|c|c|c|c|c|c|c|}
\hline $\begin{array}{c}\text { Fluconazole } \\
\text { Concentration } \\
\mathbf{u g} / \mathbf{m l}\end{array}$ & $\begin{array}{c}\text { Average } \\
\text { diameter } \\
\text { of } \\
\text { inhibition } \\
\mathbf{( m m}\end{array}$ & $\begin{array}{c}\text { (MPE) } \\
\text { Concentration } \\
\mathbf{u g} / \mathbf{m l}\end{array}$ & $\begin{array}{c}\text { Average } \\
\text { diameter } \\
\text { of } \\
\text { inhibition } \\
\mathbf{( m m}\end{array}$ & $\begin{array}{c}\text { Combination } \\
\text { (fluconazole } \\
\mathbf{+ M G A P E )} \\
\mathbf{5 0 \% + 5 0 \% )} \\
\mathbf{5 0} / \mathbf{m l}\end{array}$ & $\begin{array}{c}\text { Average } \\
\text { diameter } \\
\text { of } \\
\text { inhibition } \\
\text { (mm) }\end{array}$ & $\begin{array}{c}\text { A Synergistic } \\
\text { Percent of } \\
\text { combination } \\
\mathbf{\%}\end{array}$ \\
\hline 125 & 1.8 & 125 & $\mathrm{R}$ & 250 & 1.85 & 2.7 \\
\hline 250 & 2.26 & 250 & $\mathrm{R}$ & 500 & 2.4 & 5.9 \\
\hline 375 & 2.3 & 375 & $\mathrm{R}$ & 750 & 2.55 & 9.9 \\
\hline 500 & 2.55 & 500 & $\mathrm{R}$ & 1000 & 2.8 & 9.0 \\
\hline 750 & 3.05 & 750 & $\mathrm{R}$ & 1500 & 3.5 & 12.9 \\
\hline
\end{tabular}

Early appropriate therapy may alter the course of fungal infections especially, in immunodeficient or immunosuppressed patients. Therefore, early determination of an organism's drug susceptibility (Hadley et al., 2002 ; Hosphental et al., 2004). In studying, the inhibitory range of (MIC) of fluconazole against (C.albicans, C. parapsilosis and C. tropicalis) was between (0.25 64) ug/ml (Fahriye et al., 2013). In this study, fluconazole didn't show inhibatory effect against C.albicans at concentration $50 \mathrm{ug} / \mathrm{ml}$, the starting effect of fluconazole was at concentration (125) ug $/ \mathrm{ml}$. About (MPE) and (MGAPE) each one alone, I think the few concentrations used for the study were the same as the concentrations of fluconazole Which prevented any inhibitory effect against C.albicans.

The content of both propolis and green apple peels of phenolic compounds is due to the synergistic effect with fluconazole drug, Where propolis contains many phenolic compounds such as (Flavanone, Naringenin, Flavone, 3-Hydroxyflavone, 6-Hydroxyflavone, Morin, Chrysin, Quercetin, Galangin, Apigenin ..ect), (Marica et al., 2004). Also green apple peels contains phenolic compounds, in study; the compounds most commonly in apple peels consists (catechin, procyanidin, epicatechin and phloridzin), (Escarpa and Gonzalez, 1998). Da Silva et al., (2004) agree with me when reported, Three combinations formed by the flavonoids $(+)$-catechin hydrated, hydrated quercetin, and (-)-epigallocatechingallate at a fixed concentration with fluconazole were tested. Flavonoids alone had no antifungal activity within the concentration range tested, but when they were used as a cotreatment with fluconazole, there was significant synergistic activity.The fact that the (MPE) is more synergisticthan (MGAPE) is due to Propolis, a large complex mixture of compounds (Ricardo et al., 2015). In the end, studies about propolis and green apple peel bioactivity must start with chemical profiling of the extracts since that information is essential to 
have detailed and consistent comparative data between each type of biological activity and chemical data. This information allows extrapolating the possible activity and mechanism of action.

\section{REFERENCES}

Barn-don, L.(2018). 10 Health benefits of green apples. J. Calori. (http:// caloriebee.com/nutrition/ Green-apple-benefits).

Baydar, N.G.; Öozkan, G.; Sagdic, O. (2004). Total phenolic contents and antibacterial activities of grapes (Vitisvinifera L.) extracts. F. Control. 15, 335-339.

Bougnoux M.E.; Dupout C.; Mateo, J.; Saulnier P.; Faivre V.; Payen, D.; Nicolas - chanione M.H. (1999). Serum is more suitable than whole blood for diagnosis of systemic candidiasis by mested PCR. J. Lin Microbial. 37, 925-930.

Bueno-Silva, B.; Alencar, S.M.; Koo, H.; Ikegaki, M.; Silva, G.V.; Apimoga, M.H.; Osalen, P.L. (2013). Anti-inflammatory and antimicrobial evaluation of neovestitol and vestitol isolated from brazilian red propolis. J. Agric. Food Chem. 61, 4546-4550.

Crane, E. (1999). "History of other Products from Bees." The world History of Bee Keeping and Honey Hunting. Gerald Duckworth and Co Ltd; London, pp. 545-553.

Da Silva, C.R.; de Andrade Neto, J.B.; De Sousa C.R.; Figueiredo, N.S.; Sampaio, L.S.; Magalhães, H.I.; Cavalcanti, B.C.; Gaspar, D.M.; de Andrade, G.M.; Lima, I.S.; de Barros V.G.S.; De Moraes, M.O.; Lobo, M.D.; Grangeiro, T.B.; Nobre J.H. (2014). Synergistic effect of the flavonoid catechin, quercetin, or epigallocatechingallate with fluconazole induces apoptosis in Candida tropicalis resistant to fluconazole. Antimicrob. Agents Chemother. 58(3), 1468-78.

Eberhardt, M.V.; Lee, C.Y.; Liu, R.H. (2000). Antioxidant activity of fresh apples. J. Nature, 405, 903-904.

Escarpa, A.; Gonzalez, M.C. (1998). High-performance liquid chromatography with diode-array detection for the determination of phenolic compounds in peel and pulp from different apple varieties. J. Chromat. 823, 331-337.

Fahriye, E.; Efgan, D.G.; Iclal, B. (2013). In vitro susceptibility of candida species to four antifungal agents assessed by the reference broth microdilution method. Sci. World J. 2013 Article ID 236903, 6 p.

Frankel, E.N.; Waterhouse, A.L.; Teissedre, P.L.(1995). Principal phenolic phytochemicals in selected California wines and their antioxidant activity in inhibiting oxidation of human low-density lipoproteins. J. Agric. Food Chem.43, 890-894.

Hadley, S.; Martinez, J.A.; McDermott, L.; Rapino, B.; Syndman, D.R.(2002). Real-time antifungal susceptibility screening aids management of invasive yeast infections in immunocompromised patients. J. Antimicrob. Chemother. 49, 415-9.

Hosphental, D.R.; Murray, C.K.; Rinaldi, MG. (2004). The role of antifungal susceptibility testing in the therapy of candidiasis. Diagnostic Microbiol. Infect. Dis. 48, 153-60.

Jayaprakasha, G.K.; Selvi, T.; Sakaria, K.K. (2003). Antibacterial and antioxidant activities of grape (Vitisvinifera) seed extracts. F. Res. Int. 36, 117-122.

Junjian, R.; Mingta, F.Y.; Ahui, L.; Guowei, L.; Zhengyany, Z. (2013). Optimisation of ultrasonic assisted extracted of polyphenols from apple peel emplaying cellulose enzymolysis. Int. $J$. food Scitechnol. 48, 910-917.

Kanner, J.; Frankeel, E.; Granit, R.; German, B.; Kinsella, J.E. (1994). Natural ntioxidants in grapes and wine. J. Agric. and Food Chem., 42, 64-69.

Katzung, B.G. (Ed.), (1984). "Basic and Clinical Pharmacology". $2^{\text {nd }}$ ed. Lange Medical Publications, Los Altos, California, pp. 559-577.

Katzung, B.G. (1984). "Basic and Clinical Pharmacology". $2^{\text {nd }}$ ed. Lange Med. Publ., Los Altos, California, pp. 559-577. 
Koga, T.; Moro, K.; Nakamori, K.; Yamakoshi, J.; Hosoyama, H.; Kataoka, S.; Ariga, T. (1999). Increase of antioxidative potential of rat plasma by oral administration of proanthocyanidin-rich extract from grape seeds. J. Agric. Food Chem., 47, 1892-1897.

Lopez- Ribot, J.L.; McAtee, R.K.; Perea, S.; Kirkpatrick, W.R.; Rinaldi, M.G.; Patterson, T.F. (1999). Multiple resistance phenotypes of Candida albicans coexist uring episodes of eosopharyngeal candidiasis in human immuno- deficiency virus-infected patients. Antimicro. Ag. Chemo., 43, 1621-1630.

Marica, M.; Ivona, J.; Asja, S.; Ana, M.(2004). Optimization of chromatographic conditions in thin layer chromatography of flavonoids and phenolic acids. Croatica chem. Acta.,77(1-2), 361-366.

NCCLS, (1996). National Committee for Clinical Laboratory Standards. Performance Standards for Antimicrobial Disk Susceptibility Tests- $6^{\text {th }}$ ed. Approved Standard M2-A6. Wayne, PA. Nieva Moreno MI, Isla MI, Cudmani NG, Vattu.

Nijveldt, R.J.; Van Nood, E.; Van Hoorn, D.E.; Boelens, P.G.; Van Norren, K.; Van Leeuwen, P.A. (2001). Flavonoids: A review of probable mechanisms of action and potential applications. Am. J. Clin. Nutr., 74, 418-425.

Poulain, D.; Jouault, T. (2004). Candida albicanscell wall glycans, host receptorsand responses: elements for a decisive crosstalk. Current Op. Micro. 7, 342-349.

Ricardo, S.; Fátima, B.; Cristina, A. (2015). Propolis: a complex natural product with a plethora of biological activities that can be explored for drug development. Evidence-Based Compl. Alternative Med., 2015, 29 p.

Righi, A.A.; Alves, T.R.; Negri, G.; Marques, L.M.; Breyer, H.; Salatino, A. (2011). Brazilian red propolis: Unreported substances, antioxidant and antimicrobial activities. J. Sci. Food Agric., 91, 2363-2370.

Sagar, A. (2016). Mannitol salt agar for isolation of staphylococus aureus. (http:// w.w.w. microbiology infom.com.).

Schmidt-Westhausen, A.M.; Bendick, C.; Reichart, P.A.; Samaranayake, P. (2004). Al candidosis and associated Candida species in HIV-infected Cambodians exposed to antimycotics. Myco., 47, 435-441.

Schwab, U.; Milatovic, D.; Braveny, I. (1997). Increased adherence of Candida albicans to buccal epithelial cells from patients with AIDS. Euro. J. Clinical Micro. Infectious Dis. 16, 848851.

Shoji, T.; Akazome, Y.; Kanda, T.; Ikeda, M. (2004). The toxicology and safety of apple polyphenol extract. Food Chem. Toxi., 42, 959-967.

Sims, C.R.; Ostrosky-Zeichner, Rex, J.H. (2005). Invasive candidacies in immunocompromised hospitalized patients. Arch. Medical Res., 36, 660-671.

Van der Sluis, A.A.; Dekker, M.; De jager, A.; Jongen, W.M.F. (2001). Activity and concentration of polyphenolic antioxidants in apple: effect of cultivar, harvest year, and storage conditions. J. Agric. Food Chem., 49, 3606-3613.

Victoretal, M.M.; Claudia, I.D.; Alipio, J.S.; Breno, M.F.(2015). Floral biology and implications for apple pollination in semiarid north-eastern Brazil. J. Agric. Environmental Sci., 4, 42-50.

Zhang, C.; Huang, S.; Wei, W.; Ping, S.; Shen, X.; Li, Y.; Hu, F. (2014). Development of highperformance liquid chromatographic for quality and authenticity control of chinese propolis. J. Food Sci., 79, C1315-C1322. 